\title{
模型水平載荷試験による群杭の地盤反力〜変位関係 \\ RELATION BETWEEN SUBGRADE REACTION AND DISPLACEMENT OF MODEL PILE GROUP BASED ON HORIZONTAL LOADING TEST
}

\author{
鈴木康 嗣*，安達 直 人*** \\ Yasutsugu SUZUKI and Naohito ADACHI
}

\begin{abstract}
Horizontal loading tests were conducted to investigate the characteristics of subgrade reaction of model pile groups. The relation between subgrade reaction and pile displacement traces a triangular loop due to pile group efficiency. The coefficient of subgrade reaction of pile group decreases with decreasing ratio of space between piles and pile diameter. A front pile of pile group has large subgrade reaction at shallow position and has large bending moment and shear force at pile top. However, a rear pile has relatively large subgrade reaction, bending moment and shear force at deep position. Based on the relation between subgrade reaction and pile displacement, hysteresis models are presented and can well simulate the test results.
\end{abstract}

Keywords : Pile group, Horizontal loading test, Model test, Subgrade reaction, Pile group efficiency, Hysteresis damping factor, Bending moment, Shear force 群杭，水平载荷試験，模型実験，地盤反力，群杭効率，履歴減衰定数，曲げモーメント，せん断力

1.はじめに

筆者らは，液状化地盤が杭に及ほす力を評価するため，振動台実 験を行い，地盤反力が杭と地盤の相対变位や相対速度とどのような

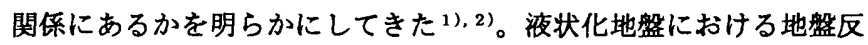
力特性を評価する上で, 初期值となる液状化前の地盤反力特性を把 握し, 弾性状態から液状化後まで連続的なモデル化を行うことが重 要である。液状化する前の地盤反力特性を実験的に求める手法とし ては, 静的, 動的な杭頭水平載荷試験や乾燥砂による振動台実験な どが考えられる。本論文では，基本的な特性を実験的に把握するこ とを目的として, 静的水平載荷試験による検討を行った。

単杭の原位固水平載荷試験はこれまで多数実施されているが, 群 杭の原位置水平載荷試験は比較的少なく ${ }^{3)}$, 同一地盤で杭本数や配置 を変えた試験(例4) 6)はさらに少ない。また, 室内における模型群杭 の水平載荷試験例7)も決して多くない。重力場や遠心場における小型 の模型試験は，相似則に基づく縮尺率が大きいため，その適用性に は問題を含んでいる。しかし，再現性の良い地盤でパラメータを多 数変えた試験が可能なことや，模型杭の材料選定に自由度があるた め杭が弾性状態のままで大変形させることが出来る等の利点がある。 杭の応力はひずみグージの值から求めるのが一般的であるため, 直接測定されるのは軸ひずみ（軸力）と軸ひずみから算出される曲
率（曲げモーメント）である。杭と地盤のカのやり取りは一般に地 盤反力と变位の関係で決まるが, 地盤反力は曲げモーメントを 2 階 微分して, 変位は曲率を 2 階積分して算出される值であるため, 地 盤反力と变位の関係を実験的に高い精度で評価するのは，特に原位 置試験では非常に難しく, 模型試験も含めて研究例8) 101 は少ない。

一方，杭の水平抵抗に関する理論的・解析的研究としては, Poulos の一連の研究11), 12)があり, 群杭現象を大局的に評価している。また,

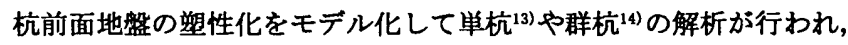
群杭模型の試験結果との対応が検討されている14)。これらの研究で は, 地盤反力と変位の関保をモデル化しているものの, 試験結果か ら直接地盤反力と变位の関係を求めている訳ではない。 そこで本論文では，地盤反力と変位の関係を高い精度で評価する ために, 重力場において模型群杭基碳の水平載荷試験を実施した。 この試験から得られた関倸を基に, 地盤反力係数, 群杭効率および 杭位置による曲げモーメントやせん断力の違いなどを実験的見地か ら検討するとともに，地盤反力〜変位関係のモデル化について検討 する。

\section{2. 水平載荷試験の概要}

試験モデルと計測点配置を図 1 に, 模型杭の配置を図 2 に, 試験
* 鹿島技術研究所建築構造グループ 上席研究員 · 工修

***鹿島技術研究所都市防災・風環境グループ 主任研究員 (広島大学大学院工学研究科社会環境システム専攻 大学院生)
Supervisory Research Engineer, Building Structure Group, Kajima Technical Research Institute, Kajima Corporation, M. Eng.

Senior Research Engineer, Disaster Prevention and Wind Engineering Group,

Kajima Technical Research Institute, Kajima Corporation

(Graduate Student, Graduate School of Engineering, Department of Social and Environmental Engineering, Hiroshima University) 


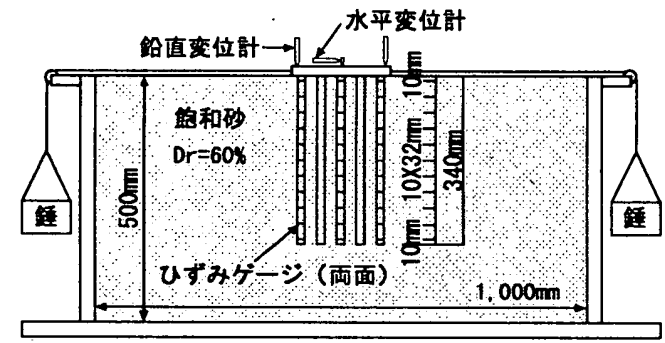

图 1 試験モテルと計測点配置

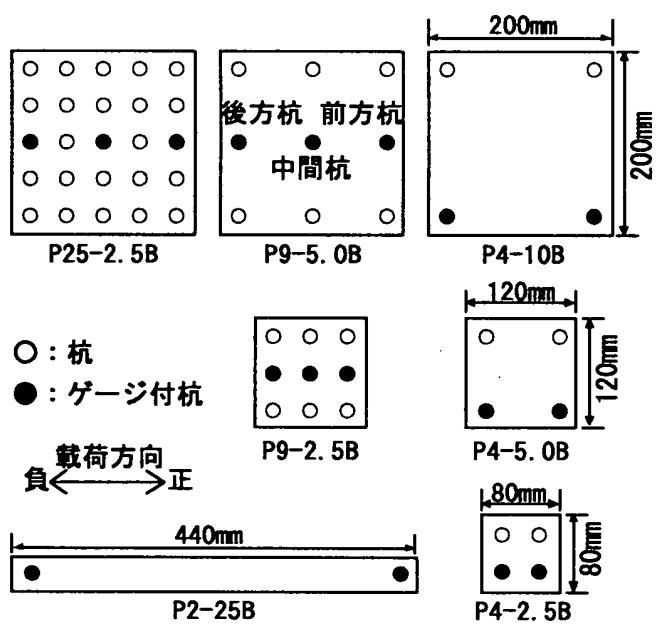

图 2 模型杭の配置と基喏形状
表 1 試験ケースと荷重ステップ

\begin{tabular}{|c|c|c|c|c|}
\hline $\begin{array}{l}\text { 㢦験 } \\
\text { ケース }\end{array}$ & $\begin{array}{l}\text { 杭本数 } \\
\text { (本) }\end{array}$ & $\begin{array}{l}\text { 杭配置 } \\
\text { 毓X横 }\end{array}$ & $\begin{array}{c}\text { 杭距部 } \\
\mathrm{R} / \mathrm{B}\end{array}$ & $\begin{array}{c}\text { 荷重ステップ } \\
( \pm N)\end{array}$ \\
\hline P2-25B & 2 & 1X2 & 25.0 & $\begin{array}{l}2.45,4.9,9.8,14.7 \\
19.6,29.4,39.2,49.0\end{array}$ \\
\hline P4-10B & 4 & $2 \times 2$ & 10.0 & \\
\hline$\frac{P 4-5.0 B}{P A-2.5 B}$ & 4 & $2 \times 2$ & 5.0 & $\begin{array}{l}4.9,8,78,4,98.0 \\
58.8,7,\end{array}$ \\
\hline$\frac{P 4-2.5 B}{P 9-5.0 B}$ & $\frac{4}{9}$ & $\frac{2 \times 2}{3 \times 3}$ & $\frac{2.5}{5.0}$ & 110221441662 \\
\hline P9-2.5B & $\frac{3}{9}$ & $\frac{\frac{30}{3 \times 3}}{3 \times 3}$ & 2.5 & \\
\hline P25-2. 5B & 25 & $5 \times 5$ & 2.5 & $\begin{array}{l}30.6,61.3,122.5, \\
183,75,245.0\end{array}$ \\
\hline
\end{tabular}

表 2 試験に用いた砂の諸元

\begin{tabular}{|c|c|c|}
\hline & 巹号（単位） & 值 \\
\hline 土粒子密度 & $\rho_{8}\left(\mathrm{~g} / \mathrm{cm}^{3}\right)$ & 2.64 \\
\hline 乾嬠密度 & $\rho_{\mathrm{d}}\left(\mathrm{g} / \mathrm{cm}^{3}\right)$ & 1.53 \\
\hline 最大密度 & $\rho_{\operatorname{dax}}\left(\mathrm{g} / \mathrm{cm}^{3}\right)$ & 1.67 \\
\hline 最小密度 & $\rho_{\min }\left(\mathrm{g} / \mathrm{cm}^{3}\right)$ & 1.40 \\
\hline 相対密度 & $\operatorname{Dr}(\%)$ & 60 \\
\hline 内部魔挜角 & $\phi($ 度) & 37 \\
\hline
\end{tabular}

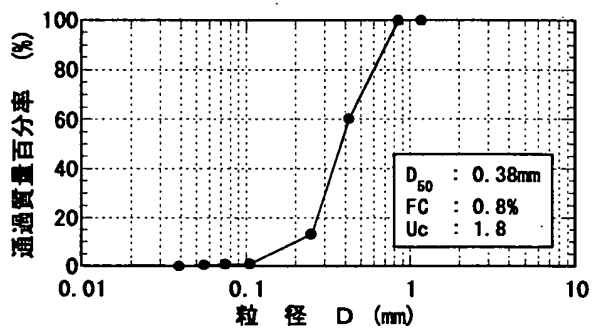

图 3 試験に用いた砂の粒径加積曲線

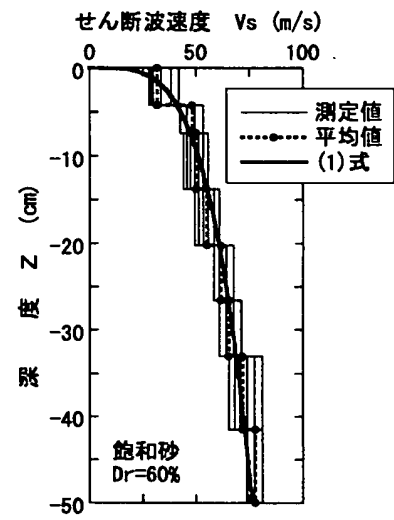

图 4 模型地盤のせん断波 速度分布

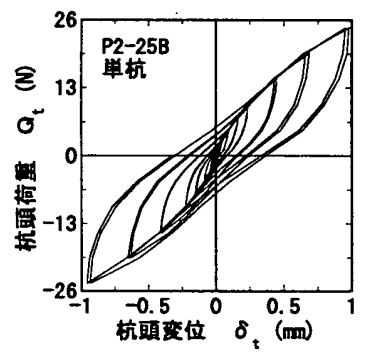

图 5 単杭の杭頭荷重 ～杭頭変位関保
ケースと荷重ステップを表 1 に示す。訊験に用いた土槽は, 振動台 実験 ${ }^{11}{ }^{2}$ )に用いた土槽(5) と同じで，高さ2cmのせん断フレームを25段 積層した幅 $1.0 \mathrm{~m} \times$ 奥行 $1.0 \mathrm{~m} \times$ 高さ0.5mのせん断土槽である。試験モ デルは杭中心間距䧺と杭径の比 $\mathrm{R} / \mathrm{B}(2.5 \sim 25)$ と杭本数 $(2 \sim 25$ 本) をパラメータとして 7 種類作製した。模型杭にはアクリル製の円筒 （長さ $\mathrm{L}=340 \mathrm{~mm}$, 外径 $\mathrm{B}_{\mathrm{o}}=16 \mathrm{~mm}$, 内径 $\mathrm{B}_{\mathrm{i}}=13 \mathrm{~mm}$, 曲け㓮性 $\mathrm{E} \mathrm{I}=$ 5. $\left.0 \mathrm{Nm}^{2}\right)$ を用いた。アクリルは，鉄やアルミに比べて降伏点の歪が 大きく, 弾性状態のままで大変形まで測定可能である。模型杭の杭 頭は, 中空部分を固定治具付きの鉄詮で塞ぎ，剛体基礎（直径 $16 \mathrm{~mm}$ の穴があいた厚さ $20 \mathrm{~mm}$ の鉄板）と固定治具をボルトで固定した。ま た，杭下端も鉄詮で塞ぎ，深さ $50 \mathrm{~cm}$ 地盤中にフリーとした。図 2 に示したゲージ付杭には, 杭内面の両側に $32 \mathrm{~mm}$ 間隔（杭外径の 2 倍）

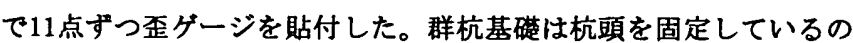
で，それに対応した単杭の試験として杭中心間距離 $\mathrm{R} / \mathrm{B}=25$ の 2 本 杭の試験も実施した。模型地盤の諸元を表 2 に, 粒径加䅡曲線を図 3に示す。模型地盤は，掁動台実験 ${ }^{2)}$ と同じ方法（ボイリング）で作 製した相対密度 $\mathrm{Dr}=60 \%$ の飽和砂を用いた。杭頭の水平荷重は, 鏵 の重量をワイヤーを介して剛体基礎に伝え, 表 1 に示した荷重ステッ プで 2 回ずつ繰返す正負交番䋘返し載荷とした。

剛体基硌の水平変位を 1 点, 鉛直変位を 4 点, $2 \sim 3$ 本の杭の曲 げひずみ（図 2参照）を梁さ方向に11点ずつ（図 1参照）湘定した。 事前に実施した片持ち梁形式のキャリブレーションから杭の曲げ剛 性 $\mathrm{E} I$ を求め, 得られた曲率に掛け合わせて曲げモーメントとした。 梁の理論に基づき，曲げモーメントを 1 階差分してせん断力を， 2 階差分して地盤反力を，曲率を 2 階積分して杭变位を算出した。

水平載荷試験および同じ方法で作成した液状化実験用の地盤で測 定したせん断波速度分布を図 4 に示す。せん断波速度は，振動台に
パルス波を入カし，地中に設置した振動実験用の加速度計で測定し た ${ }^{2)}$ 。図 4 には，12実験の測定值と平均値をプロットしている。せ ん断波速度は一般に, 平均有効主応力 $\sigma_{\mathrm{m}}{ }^{\prime}$ の0.25乗に比例すると言 われている。 $\sigma_{\mathrm{m}}^{\prime}$ を算出するには静止土圧俰数が必要であるが，静 止土压俰数を測定あるいは推定するのは非常に難しいので，せん断 波速度が有勃上載応力 $\sigma_{\mathrm{v}}^{\prime}(\mathrm{kPa})$ の0.25乗に比例するとした次式の 関係を図 4 に太実線で併記した。

$$
\mathrm{Vs}=52 \sigma_{\mathrm{v}}, 0.25 \quad(\mathrm{~m} / \mathrm{s})
$$

ここで，倸数52は測定值に最も合致する值を設定した。(1)式から求 めたせん断波速度の深度分布は概ね測定值と対応しており，作製さ れた模型地盤のせん断波速度のぼらつきは小さく, 再現性が高い地 盤模型が作成されたと判断される。

\section{3. 試験結果}

\section{1 杭頭荷重 杭頭変位関係}

単杭（R/B = 25の 2 本杭であるが，本論文では単杭として扱 う。）の杭 1 本あたりの杭頭荷重 $Q_{\mathrm{t}}$ と杭頭変位 $\delta_{\mathrm{t}}$ の関係を図 5 に示 す。基碮の水平変位は，図 1 に示したように基碮よりやや高い位置

（基礎より10〜16mm）で測定している。そこで，基礎の鉛直変位 から剛体基碮の回転角を算出し，この回転成分に起因した水平変位 を換算して杭頭（基碦下端）位置の水平変位，すなわち図 5 の杭頭 変位 $\delta_{\mathrm{t}}$ を求めている。図 5 より, 杭頭荷重と杭頭変位のループの中 央部がくびれる傾向が認められる。これは，杭背面の地盤が緩んで いるかあるいは隙間が生じているため的と考えられる。

群杭の杭 1 本あたりの杭頭荷重と杭頭変位の関係を図 6 にまとめ て示す。 $\mathrm{R} / \mathrm{B}=10$ の 4 本群杭では, 単杭と同様にループの中央部が 

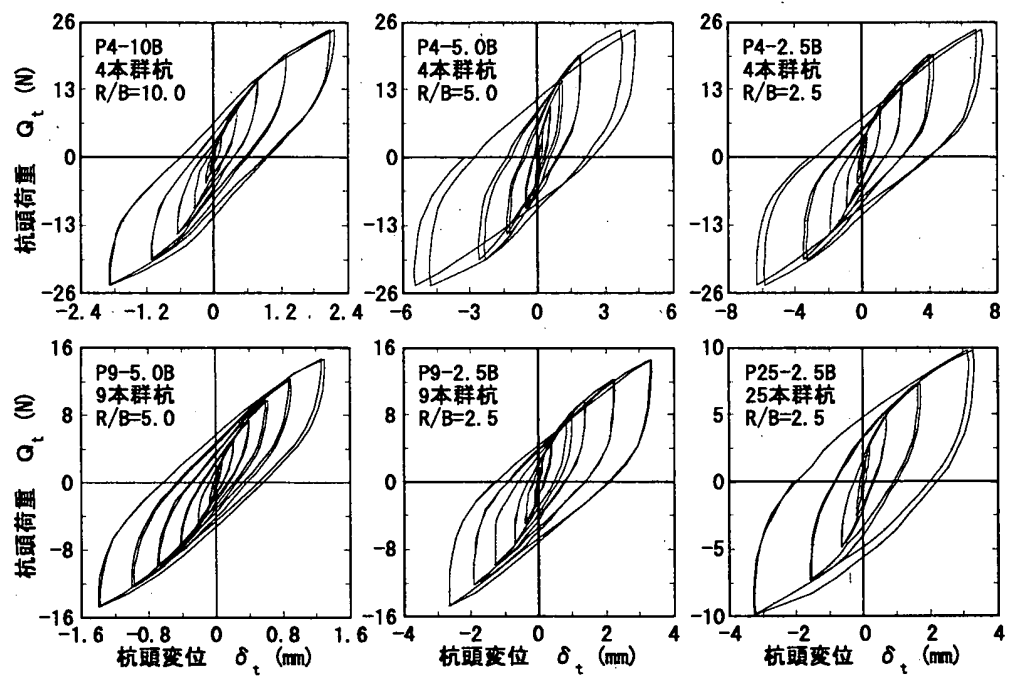

图 6 群杭の杭頭荷重〜杭頭変位関倸

くびれる傾向が認められるが，それ以外のモデルでは明確には認め られず，25本群杭ではほほ紡錘形の履歴ルーブを示した。群杭では， 杭の背後地盤がさらに背後の杭によって押されて動くため, 杭間の 地盤には緩みや隙間が生じ難いと考えられる。その結果, 杭本数が 増え， R/Bが小さくなるにうれて履歴ループのくびれが徐々に減 り，紡鍾形に近い履歷ループになったと考えられる。

なお，杭頭で最大約 $7 \mathrm{~mm}$ （杭径 $16 \mathrm{~mm}$ の約 0.4 倍）の水平変位が生 じても, アクリルは弾性頜域が広いため, 杭は塑性化していない。 従って, 原位置水平載荷試験では得られない程の大きな水平変位ま で，杭を弾性として地盤反力などを検討可能な試験になっている。

\section{2 杭頭ばね定数と履歴隇衰定数}

杭頭荷重〜杭頭変位関係の正方向側の新規荷重 ${ }^{17)}$ とそれに対応する 变位から求めた杭頭ばね定数 $\mathrm{K}_{\mathrm{t}}$ (割線剛性) と杭頭变位 $\delta$, の関俰を 図 7 に示す。杭頭変位の増加に従って杭頭ばね定数が徐々に低下寸 ることが分かる。建築基礎構造設計指針 ${ }^{18)}$ では, 群杭効率を「杭頭水 平变位量が約 $1 \mathrm{~cm}$ 時における群杭の杭頭水平荷重を同じ変位時の単 杭杭頭水平荷重を杭本数倍したもので除した值」と定義し, 群杭効 率 $\mathrm{e}$ と杭中心間距離と杭径の比 $\mathrm{R} / \mathrm{B}$ との関係を図 8 に示す実線のよ うに定めている。本試験は模型であるため, 相似則19)を考慮する必要 がある。そこで, 相似比を 100 とした場合（実杭径 $\phi=1600 \mathrm{~mm}$ の杭 頭变位 $1 \mathrm{~cm}$ が, 模型杭の杭頭変位 $\delta_{\imath}=0.1 \mathrm{~mm}$ に相当），および相似 比を 10 とした場合（実杭径 $\phi=160 \mathrm{~mm}$ の杭頭変位 $1 \mathrm{~cm}$ 型模型杭の杭 頭変位 $\delta_{\mathrm{t}}=1.0 \mathrm{~mm}$ に相当）の群杭効率を図 8 に併記した。図 8 より, 杭中心間距離が杭径の10倍でも群杭効率は0.7程度であり, 明らかに 群杭の効果が存在している。また, 全体的に本試験の群杭効率のほ うが基礎構造設計指針の值より小さく，群杭の効果が顕著である。

図 5, 図 6 に示した杭頭荷重〜杭頭变位関係から求めた履歷減衰 定数 $\mathrm{h}_{\mathrm{t}}$ と杭頭変位 $\delta_{\mathrm{t}}$ の関係を図 9 に示す。履歷減衰定数は文献 ${ }^{17)} の$ 方法に従い, 弾性エネルギーと履歴によるエネルギー消費の比とし て求めた。単杭の履歴堿衰定数は, 履歴ループの中央部がくびれる ため杭頭変位が増加してもあまり増加せず，一定值となる傾向が認 められる。一方, 群杭の履歴減衰定数は単杭に比へてやや大きく, 杭頭変位の増加に従って増える傾向が認められる。この傾向は, 杭 本数が増え, 杭間隔が狭くなるに連れて䫓著になる。

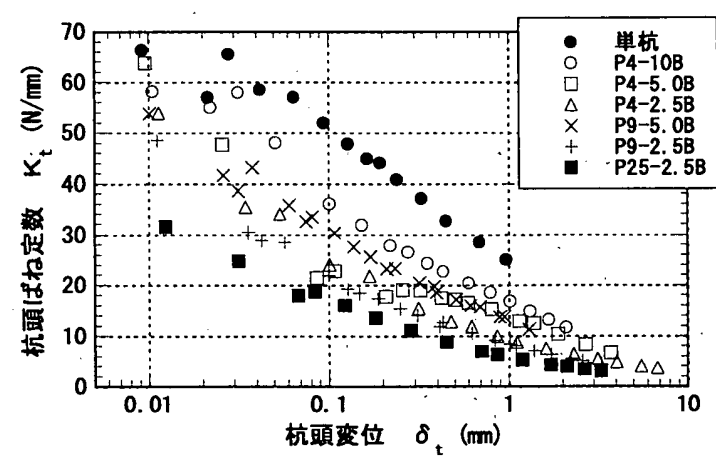

图 7 、杭頭ばね定数と杭頭变位の関係

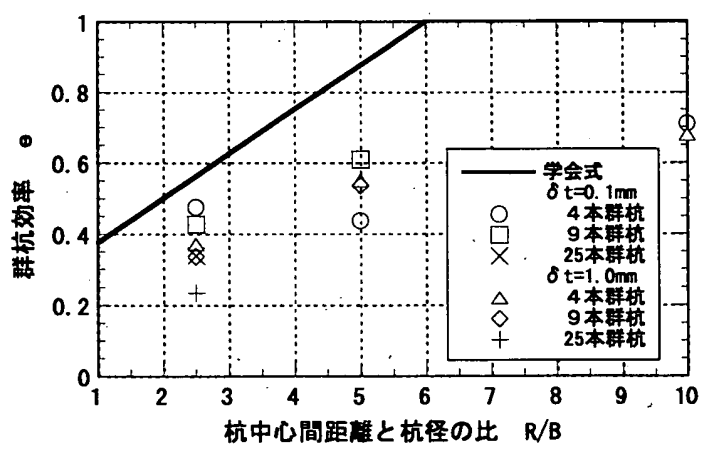

図 8 群杭効率と杭間隔の関俰

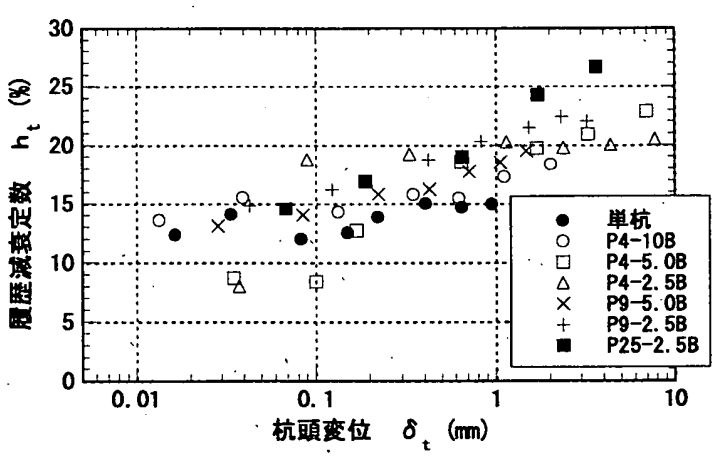

图 9 杭頭の履歴減衰定数と杭頭変位の関係
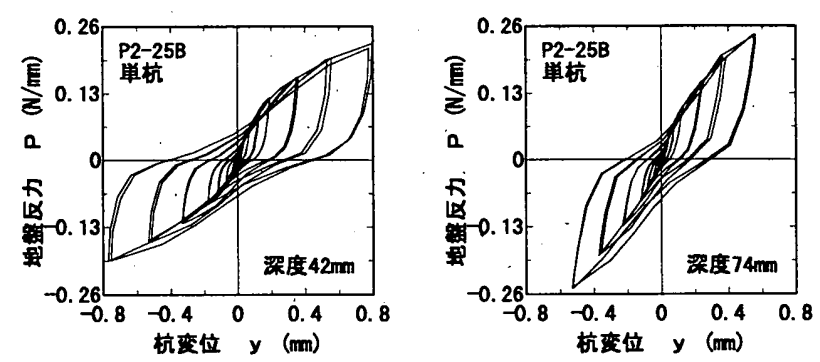

图 10 単杭の地盤反力〜杭変位関係

\section{3 地盤反カ〜杭变位関係}

単杭の深度 $42 \mathrm{~mm}$ およひ $74 \mathrm{~mm}$ 位置（杭頭から 2,3 番目のグージ位 置）における単位深さあたりの地盤反力 $\mathrm{P} （=\mathrm{p} \mathrm{B}, \mathrm{p}$ ：単位面積 あたりの地盤反力, $\mathrm{B}$ : 杭径) と同一深度の杭変位 $\mathrm{y}$ の関保を図 10 に示す。地盤反力と杭变位の関係はほほ正負対称形の履歴ループを 描き, 図 5 に示した杭頭荷重と杭頭変位の関係と同様にループの中 央部がくびれる傾向が顕著に認められる。

4 本群杭（ $\mathrm{R} / \mathrm{B}=10,5.0,2.5 ）$ の深度 $42 \mathrm{~mm}$ 位置における前方 

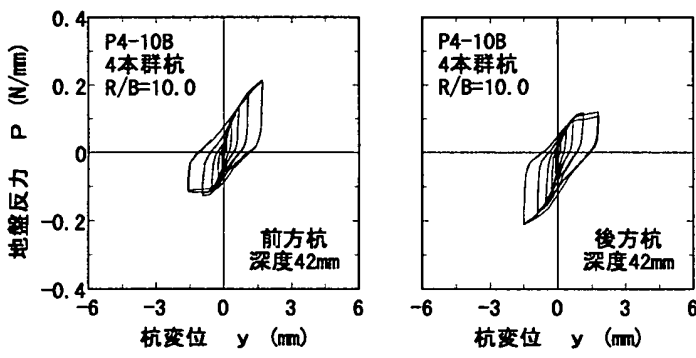

图 114 本群杭の地盤反力〜杭変位関保 $(\mathrm{R} / \mathrm{B}=10)$
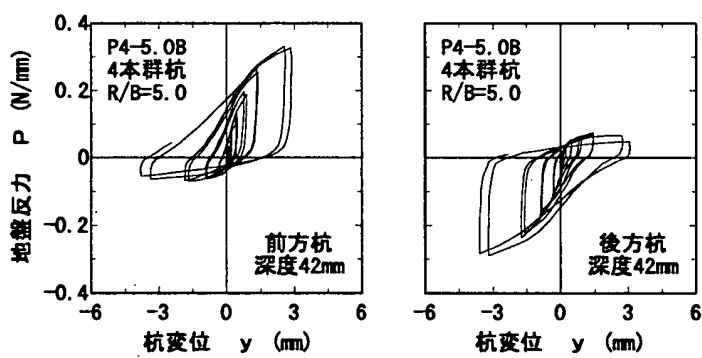

图 124 本群杭の地盤反力〜杭変位関保 $(\mathrm{R} / \mathrm{B}=5.0)$
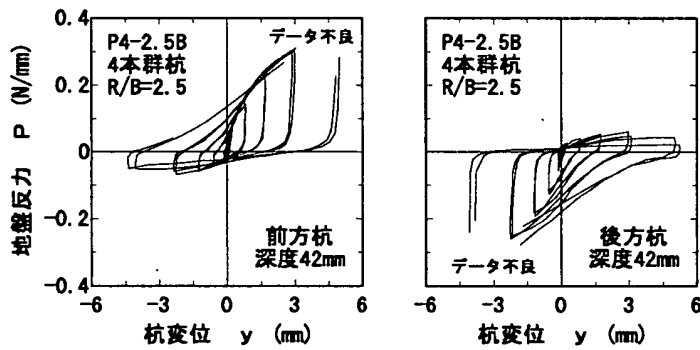

図 134 本群杭の地盤反力〜杭变位関係 $(\mathrm{R} / \mathrm{B}=2.5)$
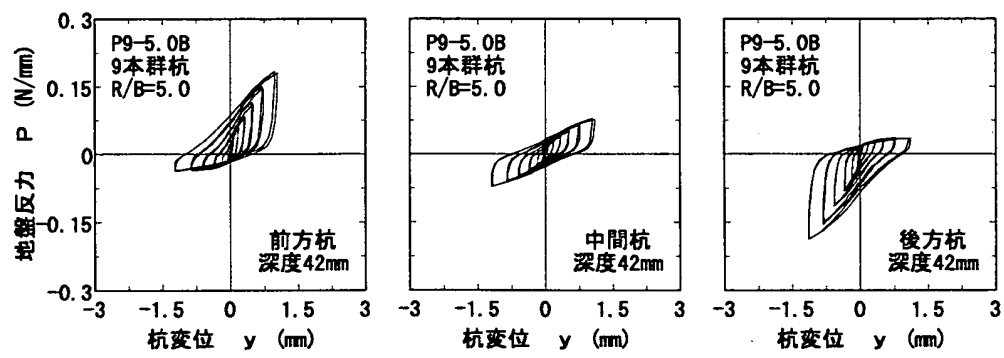

图 149 本群杭の地盤反力〜杭変位関倸 $(\mathrm{R} / \mathrm{B}=5.0)$
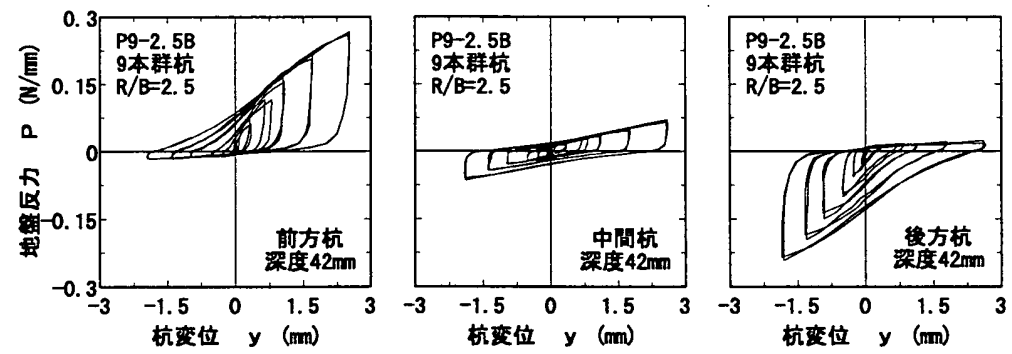

図 159 本群杭の地盤反力 杭变位関保 $(\mathrm{R} / \mathrm{B}=2.5)$
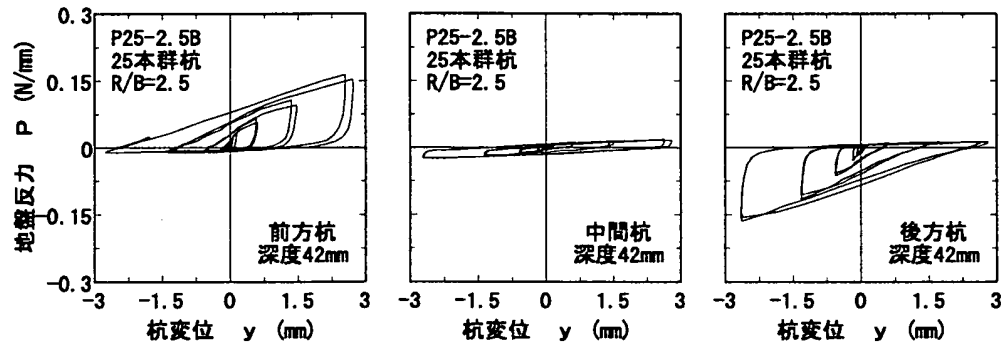

図 1625 本群杭の地盤反力〜杭变位関係 $(\mathrm{R} / \mathrm{B}=2.5)$
杭と後方杭（図 2 参照）の地盤反力と杭变位の関係を図11〜図13に 示す。図11に示した杭中心間距離が最も広いケース（R/B=10）て は, 杭変位が小さい時は正負対称形であるが，杭変位の増大につれ て杭の背面側で地盤反力が一定值に収束する傾向が認められ，降伏 していると判断される。また，杭中心間距離が狭くなるにつれて地 盤反力の降伏值が小さくなり，三角形型の履歴ループとなる。この 傾向は図13に示した杭中心間距離が最も狭いケース（ $\mathrm{R} / \mathrm{B}=2.5 ）$ ではかなり䫓著である。

9 本群杭および25本群杭の深度 $42 \mathrm{~mm}$ 位置における前方杭, 中間杭 および後方杭の地盤反力と杭变位の関保を図14〜図16に示す。前方 杭と後方杭は 4 本群杭と同様に三角形型の履歴ループとなるが, 中 間杭は正負の载荷に対して前方に杭があるため, 両側の地盤反力が 降伏して小さくなっている。また, 中間杭に比べて後方杭の方が正 方向の地盤反力が小さい。

\section{4 地盤反力係数と履歴減衰定数}

深度42mm位置における地盤反力倸数 $\mathrm{k}_{\mathrm{h}}$ と同一哚度の杭変位 $\mathrm{y}$ の関 保を図 17 (a)，（b)に示す。図17 (a)に示した 4 本群杭では, 前方杭 の地盤反力係数は単杭よりやや小さいが， R/Bによる差はそれほど 顕著ではなく，杭変位が増加するとその比はさらに縮まる傾向が認 められる。一方，後方杭は $\mathrm{R} / \mathrm{B} か ゙$ 小さいほど地盤反力係数が小さ く，群杭の効果が顕著に現れている。図17(b)に示した 9 本群杭で

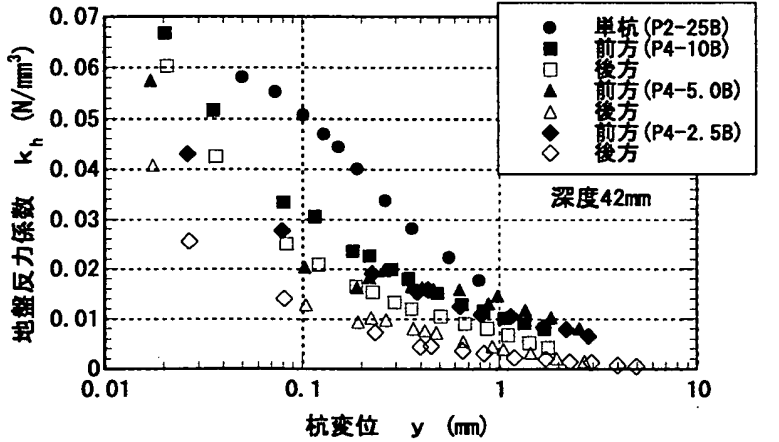

(a) 単杭および 4 本群杭

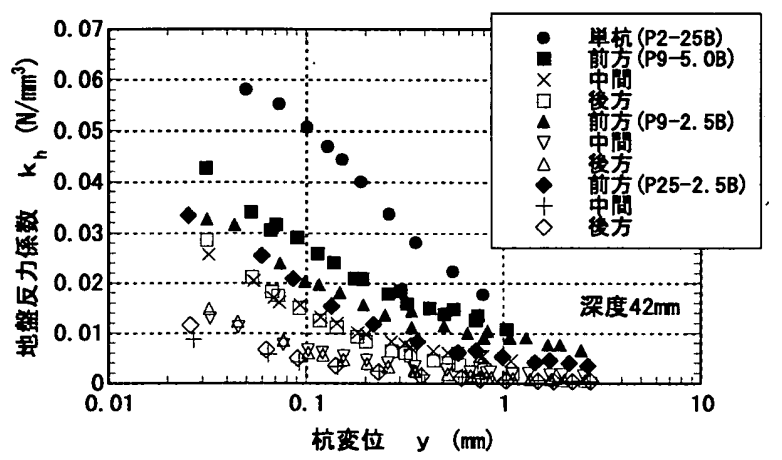

(b) 単杭，9本および 25 本群杭

图 17 地盤反力俰数と杭変位の関係 
は, 前方杭, 中間杭, “後方杭の地盤反力係数は $\mathrm{R} / \mathrm{B}$ が小さいほど小 さい。25本群杭の前方杭の地盤反力係数は, 杭変位の小さな時から 単杭の $1 / 2$ 程度である。一方, 後方杭や中間杭の地盤反力倸数は杭変 位が小さな時から単杭の $1 / 10$ 程度と非常に小さい。

哚度 $42 \mathrm{~mm}$ 位置における履歴減衰定数 $\mathrm{h}_{\mathrm{h}}$ と同一深度の杭变位 $\mathrm{y}$ の関 係を図18(a)，（b)に示す。図18(a)に示した 4 本群杭の履歴减衰定 数は, $\mathrm{R} / \mathrm{B}=5.0$ の杭変位 $0.3 \mathrm{~mm}$ 以下の場合を除き単杭に比べてや や大きい。また, 前方杭と後方杭の履歴ループは対称形なので, 履 歴减衰定数はほほ同じ值となる。図18(b)に示した 9 本群杭と25本群 杭の履歴堿衰定数は, 単杭に比べて明らかに大きい。中間杭の履歴 ループの形状は前方杭や後方杭と明らかに異なっているが、履歴減 衰定数はほほ同じである。

設計 ${ }^{18)}$ に用いる最も重要な地盤の定数は, 地盤反力保数 $\mathrm{k}_{\mathrm{h}}$ であり, 群杭の勃果により $\mathrm{k}_{\mathrm{h}}$ が小さくなるため群杭效率 $\mathrm{e}$ が 1 以下となると 解釈できる。図 7 に示した杭頭ばね定数から図 8 に示した群杭効率 を求めると，地盤反力係数の影響だけでなく，杭の曲げ棡性の影響 が含まれたものとなってしまう。これまでは地盤反力に関するテー タがそしく，しかもその特性が明らかになっていなかったため，地 盤反力から直接群杭の効果を評価することが難しかった。しかし， 群杭の効果は図17に示したような地盤反力保数から直接評価すべき である。地盤反力保数を用いれば、前方杭, 中間杭および後方杭に 生じる曲げモーメントやせん断力の差を適切に評価できる。

\section{5 地盤反力分布}

杭 1 本あたりの杭頭水平荷重が2.5N時（表 1 に示した各試験の第 2 荷重時) および9.8N時（全 7 試験のデータが揃う最大荷重時）の 前方杭，中間杭および後方杭の地盤反力分布を図19に示す。9.8N時 の場合, 前方杭の分布形状は単杭と似ているが, 最浅部を除いて群 杭の地盤反力は単杭より大きい。群杭の中間杭および後方杭の地盤 反力は，単杭に比へて浅部で小さいが，逆に中間部や樑部で大きい。 特に25本群杭の後方杭では, 深部の地盤反力が浅部よりも明らかに 大きい。すなわち, 群杭の浅部では前方杭が大きな地盤反力を受け 持ち，中間杭や後方杭の地盤反力は小さくなる。一方，中間部や樑 部では中間杭や後方杭が大きな地盤反力を受け持っている。

杭頭水平荷重が2.5N時でも9.8N時と同様の傾向が認められるが, 9. 8N時に比べてその傾向が明確でなく，単杭と群杭の地盤反力分布 の差は特に前方杭において小さい。これは, 杭頭荷重あるいは杭頭 変位が增大すると, 群杭の特性がさらに顕著に発揮されることを示 している。

\section{6 杭変位分布}

杭 1 本あたりの杭頭水平荷重が9.8N時の 9 本群杭（ $R / B=5.0$; 2.5）および25本群杭（ $R / B=2.5 ）$ の杭変位分布を図 20 に示す。 杭頭を基䃈に剛接しているため 3 本の杭变位は深度 $0 \mathrm{~cm}$ で一致して いる。前方杭は浅部で大きな地盤反力を受けるため，杭が急激に曲 げられて地中部の杭変位が小さくなるが，中間杭や後方杭では浅部 の地盤反力が小さいために杭はあまり曲げられず，墚度 $15 \mathrm{~cm}$ 付近ま では直線的な杭変位分布を示す。そのため, 地中部の杭変位は前方 杭よりも大きくなる。一方, 媣部では中間杭や後方杭に比較的大き な地盤反力が生じて杭が曲げられている。このように, 群杭では地

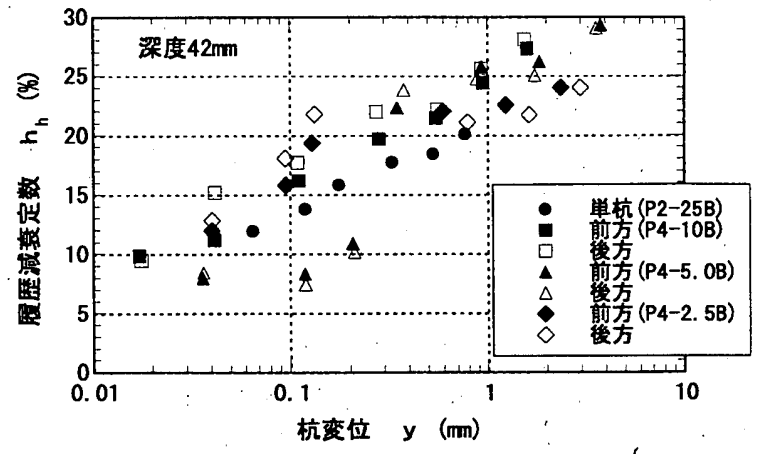

(a) 単杭および 4 本群杭

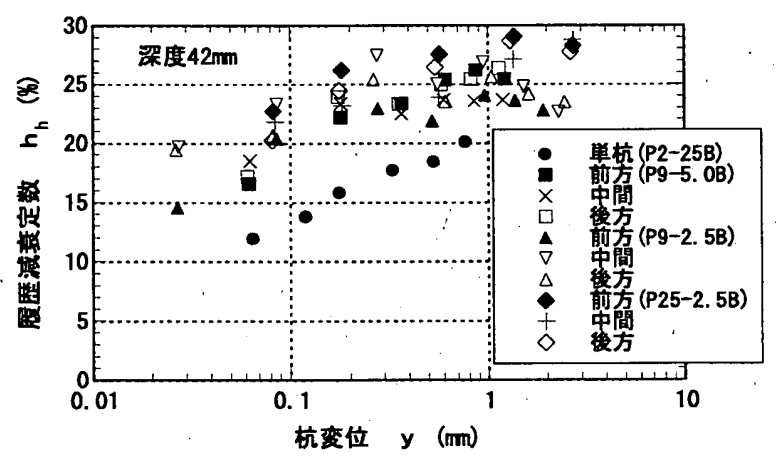

(b) 単杭，9本および 25 本群杭

图 18 履歷減衰定数と杭変位の関保

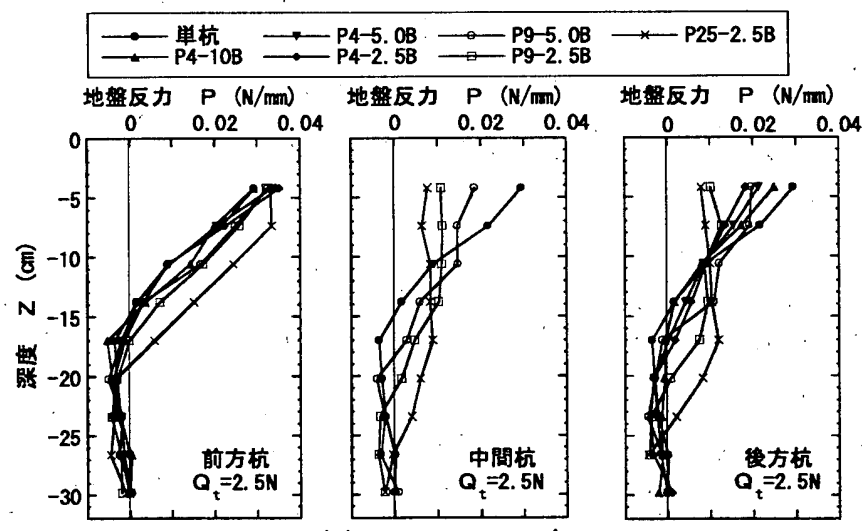

(a) $\mathrm{Q}_{1}=2.5 \mathrm{~N}$ 時
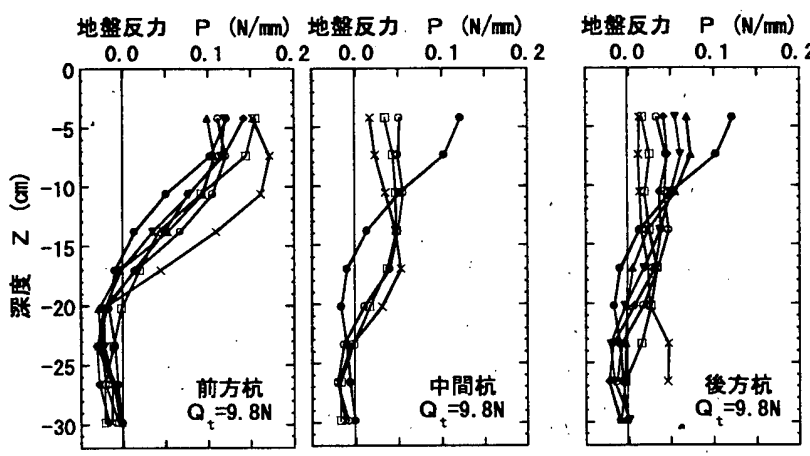

(b) $\mathrm{Q}_{\mathrm{t}}=9.8 \mathrm{~N}$ 時

图 19 単杭および群杭の地盤反力分布

盤反力のみならず杭の变形も杭位置によって異なっている。なお， 9 本群杭の 3 本の杭下端変位はほぼゼロになるが，25本群杭では杭 下端も回転して 3 本の杭下端変位は負になっている。 


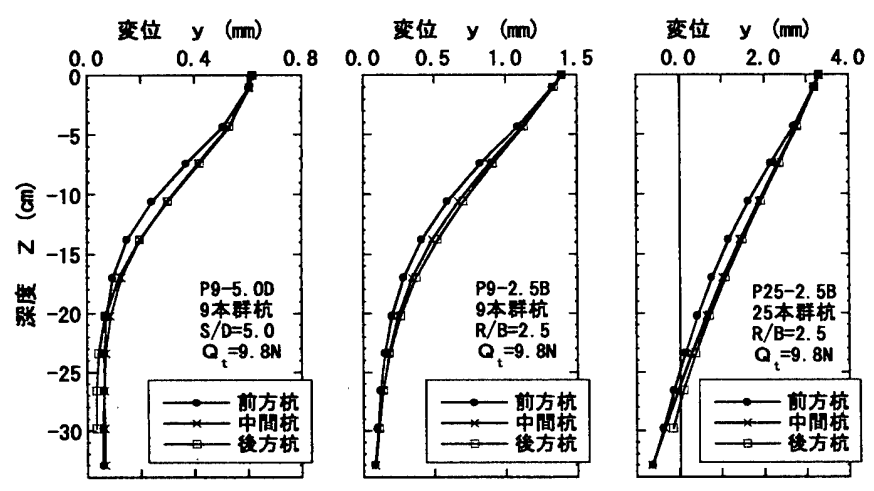

图 209 本群杭および 25 本群杭の杭变位分布
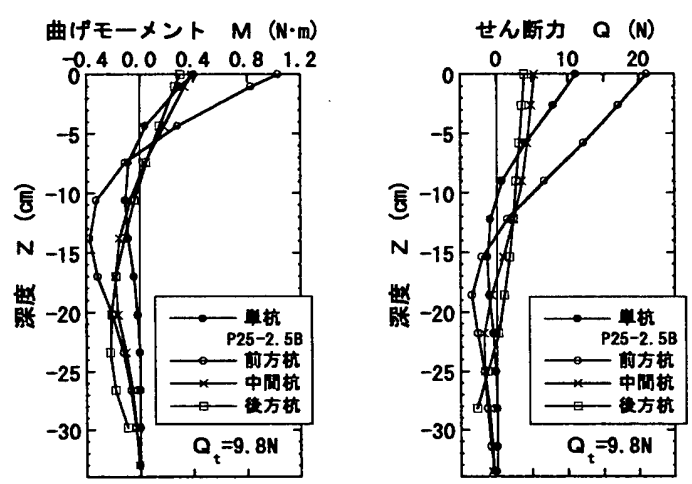

图 21 単杭およひ 25 本群杭の曲げモーメント分布とせん断力分布

\section{7 杭の曲げモーメントとせん断カ}

25本群杭の曲げモーメント分布およびせん断力分布を単杭と比較 して図21に示す。前方杭の杭頭曲げモーメントは単杭に比べて2.5倍 程度大きく, 地中部曲げモーメントの最大值発生深度は単杭に比へ て前方杭, 中間杭, 後方杭の順番で梁くなる。また, 地中部最大曲 げモーメントは単杭に比へていずれの杭でも大きい。せん断力分布 にも曲げモーメント分布と同様の傾向が認められ，前方杭の杭頭せ ん断力（杭頭の水平力）は単杭の 2 倍程度大きく, 中間杭, 後方杭 では半分以下である。

杭頭の水平力分担比（曲げモーメントから求めた杭頭のせん断力 $\mathrm{Q} /$ 杭 1 本あたりの杭頭荷重 $\mathrm{Q}_{\mathrm{t}}$ ) と杭頭荷重 $\mathrm{Q}_{\mathrm{t}}$ の関倸を図 $22(\mathrm{a})$, (b)に示す。前方杭は図 19に示したように大きな地盤反力を受け持 つため, 杭頭荷重の增加と共に水平力分担比が増え、最大では 2 倍 以上になっている。一方，中間杭や後方杭では浅部において地盤反 力をあまり負担しないので, 徐々に水平力分担比が減り，最小では 半分以下になっている。また,これらの傾向は $\mathrm{R} / \mathrm{B}$ が小さいほど影 著である。

以上のように，群杭では杭の位置によって地盤反力分布が大きく 異なるため, 曲げモーメントやせん断力などの杭に生じる応力の最 大值が杭位置によっては 2 倍以上も異なっている。これらの杭応力 を適切に評価することが杭の設計において重要であると考える。

\section{4. 地盤反カ〜変位関係のモテル化}

\section{1 試験結果に基づくモデル化}

建築基碮構造設計指針18) では，単位深さあたりの杭の地盤反力 $\mathrm{P}$,

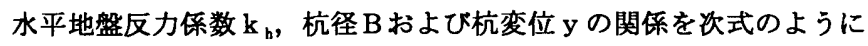
定義している。

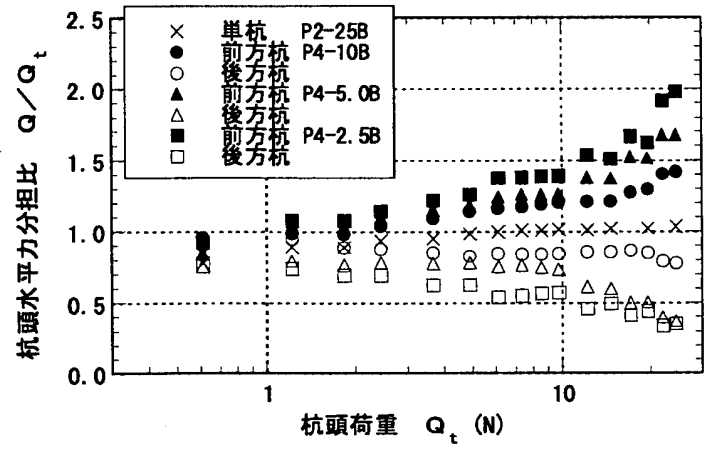

(a) 単杭および 4 本群杭

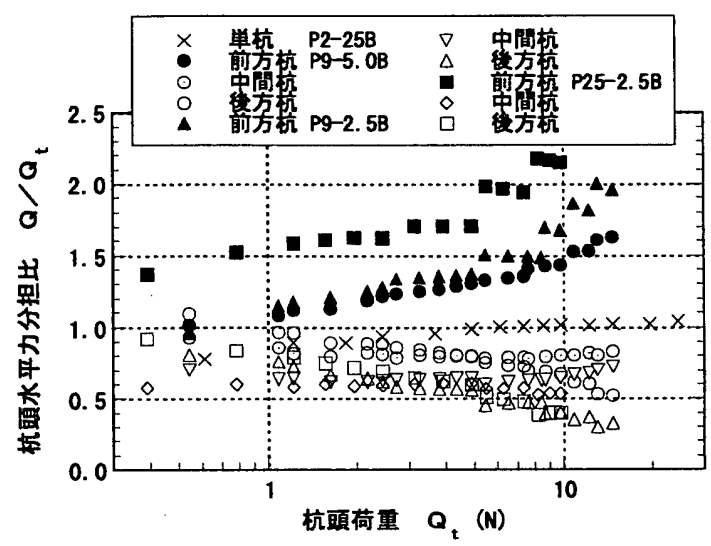

（b）単杭，9本および 25 本群杭

图 22 杭頭の水平力分担比と杭頭荷重の関係

$$
\begin{aligned}
& P=p B=k_{h} B y \\
& k_{h}=k_{h 1}\left(y / y_{1}\right)^{-0.5}
\end{aligned}
$$

ここで, $\mathrm{y}$ は杭変位 $(\mathrm{cm}), \mathrm{y}_{1}$ は基準変位 $(=1.0 \mathrm{~cm}), \mathrm{k}_{\mathrm{h} 1}$ は基準変 位 $\mathrm{y}_{1}$ における基準地盤反力係数である。本模型試験のような杭径の 小さなモデルに対して $1 \mathrm{~cm}$ 基準変位は大きすぎると考えられる。 そこで, 文献10)に示されている杭径の $1 \%(=0.16 \mathrm{~mm})$ を基準変位と考 え, 地盤反力係数と無次元化変位 $\left(\mathrm{y} / \mathrm{y}_{1}\right)$ の関俰を両対数表示で図 23に示す。いずれの杭もある範囲の無次元化変位に対して直線関保 が認められるが,すへての範囲において直線関係が成立しているわ けではない。また，単杭では無次元化変位が0.5程度以上の範囲でそ の傾きがほぼ-0.5となっており，(3)式の関保が確認できる。しか し, 黒塗印で示した前方杭の傾きの絶対值は0.5より小さく，逆に後 方杭の傾きの絶対值は0.5より大きい傾向が認められる。そこで, 群 杭の地盤反力係数は $\left(\mathrm{y} / \mathrm{y}_{1}\right)$ の-0.5乗にこだわらず, 一n 乗とする指 数関数が現実的である。すなわち，

$$
k_{h}=k_{h 1}\left(y_{1} / y_{1}\right)^{-n}
$$

比較的直線関係が認められる变位 $0.1 \mathrm{~mm}$ 以上 $\left(\mathrm{y} / \mathrm{y}_{1}\right.$ で0.625以上) の範囲のデータを用いて (4) 式によって回帰した結果を表 3 に示す。 $\mathrm{n}$ の值は単杭と 4 本群杭 $(\mathrm{R} / \mathrm{B}=10)$ の前方杭ではほほ 0.5 , それ 以外の前方杭では0.5以下，後方杭では0.5以上の值となっている。 特に, 25本群杭の後方杭では0.87となり，0.5とはかけ離れている。

(3)式の関係は, 地盤反力が最大值を持たないので設計上問題が生 じる可能性があるため，建築基䃈構造設計指針18)では地盤反力に上限 を定めている。しかし，これでは曲線の連続性が損なわれる。初期 


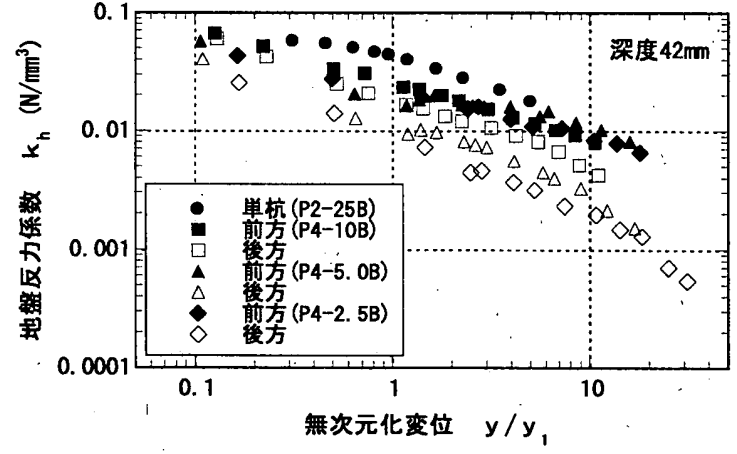

(a) 単杭および 4 本群杭

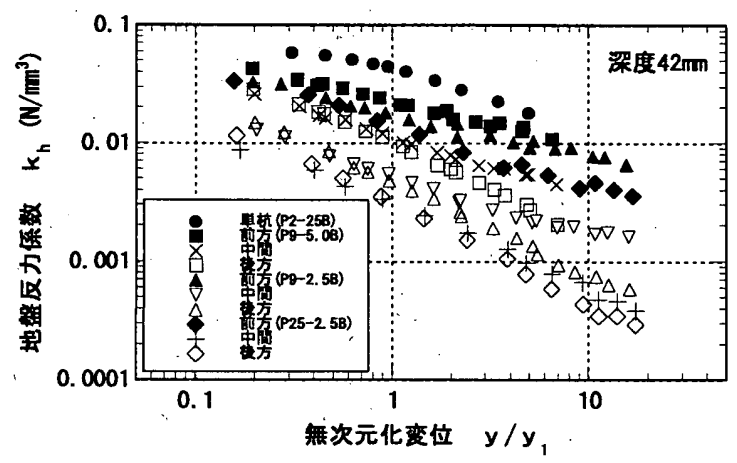

(b) 単杭，9本および 25 本群杭

图 23 両対数表示による地盤反力係数と無次元化变位の関保

值と最大值を有する単純な連続曲線として双曲線関数がある。双曲 線関数は，地盤のせん断応力とせん断ひずみの関係においてH-Dモ デル20)として知られている。そこで, 次式に示す双曲線関数を定義し た。

$$
\begin{aligned}
& \dot{\mathrm{k}}_{\mathrm{h}}=\mathrm{k}_{\mathrm{h} 2} /\left(1+\mathrm{y} / \mathrm{y}_{2}\right) \\
& \mathrm{p}_{\mathrm{naz}}=\mathrm{k}_{\mathrm{h} 2} \mathrm{y}_{2}
\end{aligned}
$$

ここで， $\mathrm{k}_{\mathrm{h} 2}$ は初期地盤反力係数， $\mathrm{p}_{\text {max }}$ は単位面積あたりの最大地盤 反カ， $\mathrm{y}_{2}$ は基準変位 $\left(=\mathrm{p}_{\mathrm{bax}} / \mathrm{k}_{\mathrm{b} 2}\right)$ である。また，(5)式は次式に 変換できる。

$$
1 / \mathrm{k}_{\mathrm{h}}=1 / \mathrm{k}_{\mathrm{h} 2}+\mathrm{y} / \mathrm{p}_{\mathrm{nax}}
$$

$1 / \mathrm{k}_{\mathrm{h}}$ と杭変位 $\mathrm{y}$ の関倸を単杭と前方杭，およびそれ以外に分けて図 24に示す。また，比較的直線関保が認められる変位 $0.1 \mathrm{~mm}$ 以上の範囲 のデータを用いて(5)式によって回㷌した結果を表 3 に示す。図23の 関係と同様に, いずれの杭もある範囲の水平変位に対して直線関保 が認められ，(5)式の関係が成り立っているが，すへての範囲で直線 関係が成立しているわけではない。

図23と図24を比較すると，相関が良い変位の範囲が異なり，一概 にどちらの関係が良いかを判断するのは難しい。，また，(3)式ではモ デ定数が基準地盤反力俰数 $\mathrm{k}_{\mathrm{h} 1}$ だけであるが，(4) 式で指数 $\mathrm{n}$ をモ デ定数とすることでモデル定数が二つとなり，(5)式で最大地盤反 力 $\mathrm{p}_{\max }$ を变えるのと同様に, 同一の基準地盤反力係数に対して異なっ た非線形特性を定義できる。この点でも，(4)式と (5) 式の優劣を判 断するのは難しい。

（4）式と（5）式に基づき，杭変位が0. $1 \mathrm{~mm}$ 以上の範囲のテータを用 いて回帰した $\mathrm{k}_{\mathrm{h} 1}, \mathrm{k}_{\mathrm{h} 2}$ （表 3 参照）と R/Bの関係を図25に示す。

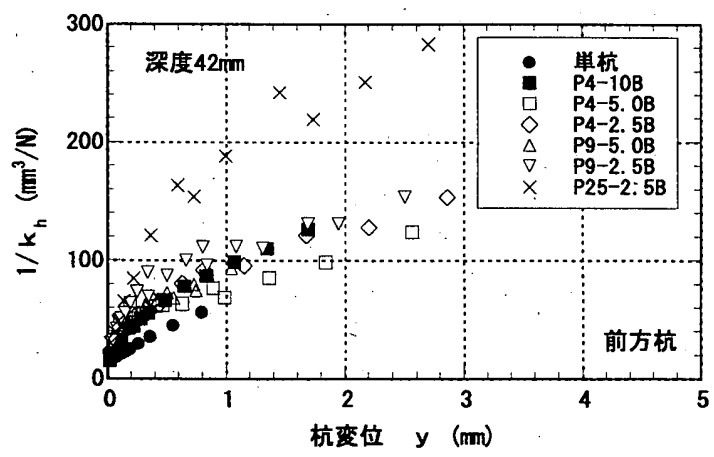

(a) 単杭および群杭の前方杭

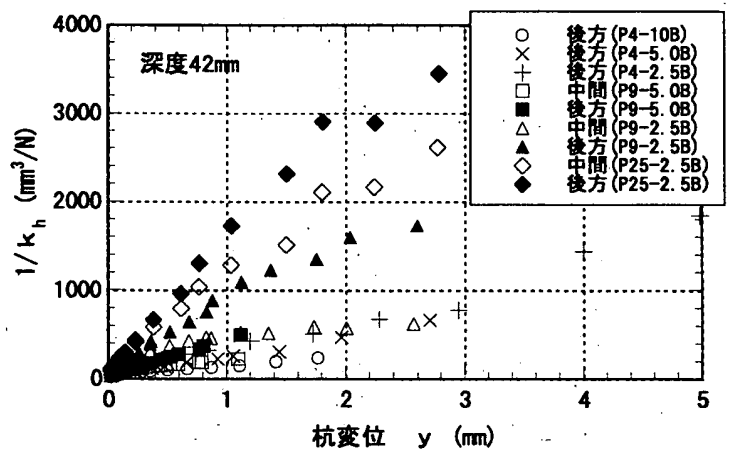

（b）群杭の中間杭および後方杭

\begin{tabular}{|c|c|c|c|c|c|c|c|}
\hline \multirow{2}{*}{$\begin{array}{l}\text { 詁験 } \\
\text { ケース }\end{array}$} & \multirow{2}{*}{$\begin{array}{c}\text { 杭本数 } \\
\text { (本) }\end{array}$} & \multirow[b]{2}{*}{$\begin{array}{c}\text { 杭虽離 } \\
R / B\end{array}$} & \multirow[b]{2}{*}{ 杭位置 } & \multicolumn{2}{|c|}{ (4)式 } & \multicolumn{2}{|c|}{ (5) 式 } \\
\hline & & & & $\begin{array}{c}\mathbf{k}_{\mathrm{h1}} \\
\left(\mathrm{N} / \mathrm{mm}^{3}\right)\end{array}$ & $n$ & $\begin{array}{c}k_{\mathrm{h} 2} \\
\left(\mathrm{~N} / \mathrm{mm}^{3}\right)\end{array}$ & $\begin{array}{c}p_{\max } \\
\left(\mathrm{N} / \mathrm{mm}^{2}\right)\end{array}$ \\
\hline P2-25B & 2 & 25.0 & 單杭 & 0.042 & 0.52 & 0.067 & 0.019 \\
\hline \multirow{2}{*}{ P4-10B } & \multirow{2}{*}{4} & \multirow{2}{*}{10.0} & 前方 & 0.026 & 0.50 & 0.030 & 0.017 \\
\hline & & & 後方 & 0.019 & 0.57 & 0.026 & 0.0092 \\
\hline \multirow{2}{*}{$\mathrm{P} 4-5.0 \mathrm{~B}$} & \multirow{2}{*}{4} & \multirow{2}{*}{5.0} & 箭方 & 0.020 & 0.26 & 0.021 & 0.036 \\
\hline & & & 後方 & 0.013 & 0.65 & 0.025 & 0.0046 \\
\hline \multirow{2}{*}{ P4-2. 5B } & \multirow{2}{*}{4} & \multirow{2}{*}{2.5} & 前方 & 0.023 & 0.42 & 0.019 & 0.028 \\
\hline & & & 後方 & 0.011 & 0.79 & 0.052 & 0.0030 \\
\hline \multirow{3}{*}{$\mathrm{Pg}-5.0 \mathrm{~B}$} & \multirow{3}{*}{9} & \multirow{3}{*}{5.0} & 前方 & 0.022 & 0.37 & 0.026 & 0.018 \\
\hline & & & 中間 & 0.011 & 0.47 & 0.013 & 0.0068 \\
\hline & & & 後方 & 0.010 & 0.80 & 0.028 & 0.0025 \\
\hline \multirow{3}{*}{$\mathrm{Pg}-2.5 \mathrm{~B}$} & \multirow{3}{*}{9} & \multirow{3}{*}{2.5} & 前方 & 0.017 & 0.33 & 0.016 & 0.026 \\
\hline & & & 中間 & 0.0050 & 0.46 & 0.0045 & 0.0051 \\
\hline & & & 荇方 & 0.0046 & 0.77 & 0.0062 & 0.0015 \\
\hline \multirow{3}{*}{$\mathrm{P} 25-2.5 \mathrm{~B}$} & \multirow{3}{*}{25} & \multirow{3}{*}{ 2. 5} & 前方 & 0.013 & 0.48 & 0.011 & 0.013 \\
\hline & & & 中間 & 0.0032 & 0.74 & 0.0038 & 0.0011 \\
\hline & & & 弦方 & 0.0031 & 0.87 & 0.0039 & 0.0008 \\
\hline
\end{tabular}

图 24 地盤反力保数の逆数と杭变位の関保

表 3-（4）式，(5) 式による回㛿分析結果

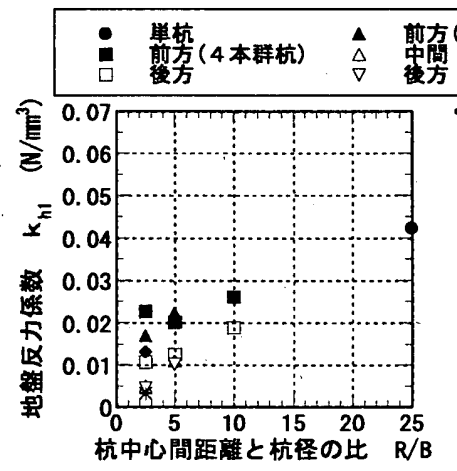

(a) $\mathrm{k}_{\mathrm{h} 1}$

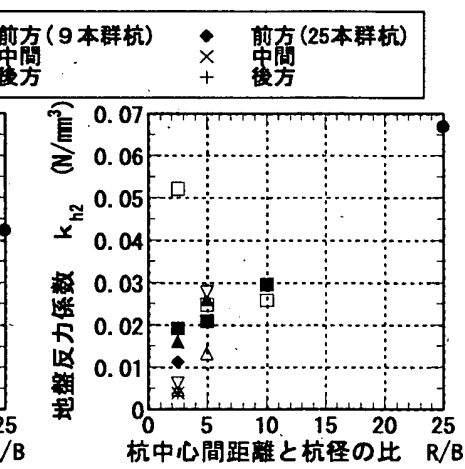

(b) $k_{h 2}$
图 $25 \mathrm{k}_{\mathrm{h} 1}, \mathrm{k}_{\mathrm{h} 2}$ と R/Bの関倸

$\mathrm{k}_{\mathrm{h} 1}$ と $\mathrm{k}_{\mathrm{h} 2}$ は $\mathrm{R} / \mathrm{B}$ が小さくなるに従って減少し, 群杭効果で地盤反 力俰数の初期值が小さくなる傾向が明らかである。また, $\mathrm{k}_{\mathrm{h} 1}$ が $\mathrm{k}_{\mathrm{h} 2}$ 
より全体的に大きいが，これは基準変位 $\mathrm{y}$ 、の採り方によって変わる ものである。

\section{2 両モデルと試験結果の比較}

表 3 に示した (4) 式，(5)式のモデル定数を用いて，試験結果の地 盤反力〜変位関保と両モデルを比較した。単杭， 4 本群杭 $(\mathrm{R} / \mathrm{B}=$ 10)，9本群杭 $(R / B=5.0)$, および 25 本群杭 $(R / B=2.5)$ の深度 42m位置における比較結果を図26に示す。群杭の場合は，前方杭の 地盤反力の負側を後方杭と考え, 前方杭と中間杭のみを示した。ど ちらのモデルも試験結果と非常に良く対応している。従って，(4)式 の指数関数の指数 $\mathrm{n}$ をモデル定数と考えれば，指数関数モデルと双 曲線関数モデルは地盤反力〜变位関係のモデルとして利用可能であ ると考えられる。なお，データで回帰した範囲を超えた部分では， 双曲線関数モデルの地盤反力が急激に降伏する傾向があるのに対し て，指数関数モテルル゙は徐々に增加する傾向があるので，図26(b)に 示した前方杭の負側（後方杭に相当）の地盤反力の急激な降伏現象 を表現するには，最大地盤反力が明確な双曲線関数モデルが適して いる。しかし，中間杭のように地盤反力が徐々に增加する傾向が続 いている場合には，指数関数モデルが適していると考えられる。

\section{5. まとめ}

群杭の地盤反力特性を把握するため, 模型群杭基礎の水平載荷試

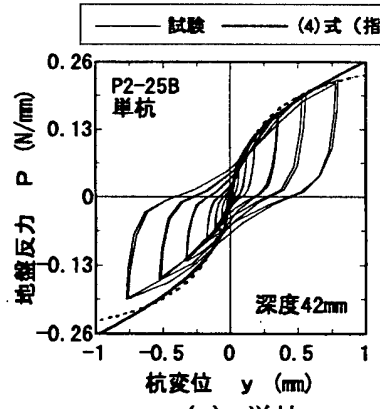

(a) 単杭

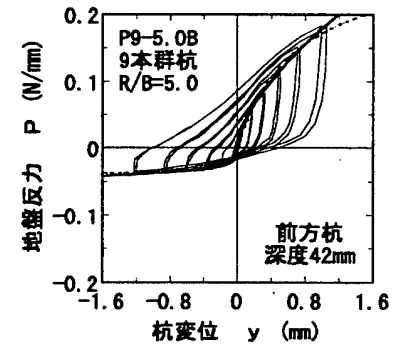

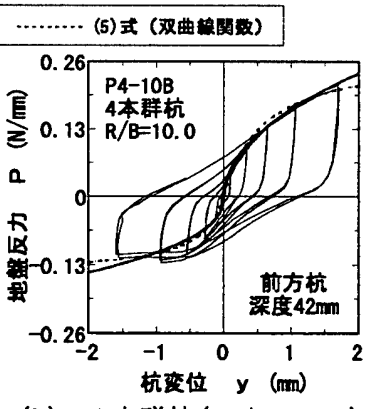

(b) 4 本群杭 $(\mathrm{R} / \mathrm{B}=10)$

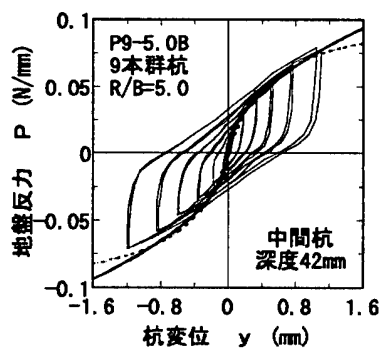

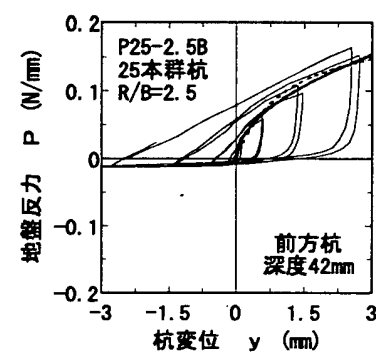

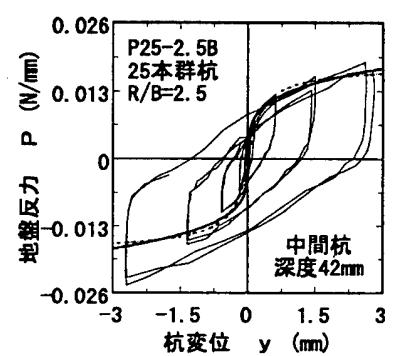

(d) 25 本群杭 $(\mathrm{R} / \mathrm{B}=2.5)$

图 26 指数関数モデル, 双曲線関数モテルと実験結果の比較
験を行った。得られた知見は以下のとおりである。

a）群杭の地盤反力〜変位関係は，前方杭と後方杭の背面側で地盤 反力が降伏して三角形型の履歴ループを描き, 中間杭では両方 向で地盤反力が降伏して小さくなる。

b) 群杭効果は杭中心間距離 (R/B)が狭くなるほど影著であるが， 杭中心間距離が杭径の10倍あっても生じている。

c）浅部では前方杭が大きな地盤反力を受け持ち，中間杭や後方杭 の地盤反力が小さくなる。一方, 中間部や深部では中間杭や後 方杭が大きな地盤反力を受け持つ。

d）前方杭は荷重の増加と共に水平力の分担比が増え，中間杭や後 方杭では減る。また，これらの㑯向は杭中心間距雕が狭いほど 顕著である。

e）地盤反力〜変位関倸の非線形性は，双曲線関数モデルとともに， 指数 $\mathrm{n}$ をテテル定数とする指数関数モデルでも表現可能である。

今後, 理論的・解析的な検討を加え, 群杭の水平抵抗問題を解明 して行く予定である。

\section{参考文献}

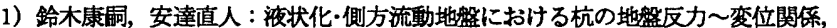
波状化メカニスム・予測法と設計法に関するシンポジウム発表論文集, 地盤工 学会, pp. 531 538, 1999

2) Suzuki, Y. and Adachi, N. : Characteristics of lateral ground force acting on pile in liquefied soil, Proc. of the 15th International Conference on Soil Mechanics and Geotechnical Engineering, pp.1015-1019, 2001

3）地盤工学会 : 杭の载荷試験に関する文献データベース，基磁構造物の限界状船 設計に関寸る研究委員会資料集，pp. IV-21 IV-33，1996

4）柴田徹, 佐藤忠信, 北口清, 山崎洋: 群杭の静的水平抵抗関する実験的研究, 第15回土質工学研究発表会講演集，pp. 981 984，1980

5）芳賀孝成，崎本純治，士屋幸三郎：群杭の水平抵抗に関する模型実験，第16回 土質工学研究発表会講演集，pp. 997 1000, 1981

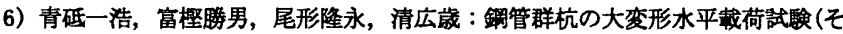
の1 試験概要)，土木学会第55回年次学術譜演会， III-B, pp. 12 13，2000

7）富永晃司，山肩邦男：矽地盤中の模型群ぐいに関する水平载荷圾倹結果と理論 的考察，日本建築学会論文報告集，第326号，pp. 68-77，1983.4

8）森伸一郎，込山貴士，木村亮：遠心場において推定された杭の水平地盤反力特 性, 第36回地盤工学研究発表会, pp. 1657 1658, 2001

9）大川寛，末政直晃，片田敏行，垉井宜幸：遠心場における杭の水平交番载荷試 験, 第36回地盤工学研究発表会培演集, pp. 1659 1660，2001

10）時松孝次，鈴木比呂子，佐伯英一郎：実大杭の杭頭およひ地中水平截荷語路に 基了く地盤反力变位関係，日本建築学会構造系論文集，第562号，pp. 53〜 58, 2002. 12

11) Poulos, H. G. : Behavior of laterally loaded piles: II-Pile groups, Journal of the Soil Mechanics and Foundations Division, ASCE, Vol.97, No.SM5, PP.733-751, 1971.5

12) Poulos, H. G. : Lateral load-deflection prediction for pile groups, Journal of the Geotechnical Engineering Division, ASCE, Vol.101, No.GT1, PP.19-34, 1975.1

13）岸田英明，中井正一：地盤の破罗を考慮した杭の水平抵抗，日本建等学会論文 報告集，第281号，pp. 41-53，1979.7

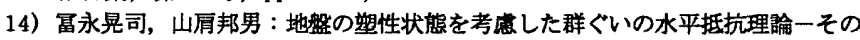
1 塑性地船反力について一, 日本建筑学会論文報告集，第317号，pp. 32-40, 1982.7

15）鈴木康㗅，安達直人，内藤幸雄，津川恒久：波状化時の地盤の大变形を再現可 能なせん断士槽の開発，日本建築学会技街報告集，第11号，pp. 57〜 60, 2000.12

16) Kishida, H., Suzuki, Y. and Nakai, S. : Behavior of a pile under horizontal cyclic loading, Proc. of the 11th International Conference on Soil Mechanics and Foundation Engineering, pp.1413-1416, 1985

17）地盤工学会 : 杭の鉛直載荷試㙠方法・同解説，2002

18）日本建築学会：建築基碟構造設計指針，2001

19) Iai, S. : Similitude for shaking table tests on soil-structure-fluid model in $1 \mathrm{~g}$ gravitational field, Soils and Foundations, Vol.29, No.1, pp.105-118, 1989.3

20) Hardin, B. O. and Drnevich, V. P. : Shear modulus and damping in soils: Design equations and curves, Journal of the Soil Mechanics and Foundations Division, ASCE, Vol.98, No. SM7, pp.667-692, 1972.7

(2003年 2 月 7 日原稿受理, 2003 年 5 月 15 日採用決定 